\title{
Immunolocalisation of matrix metalloproteinase 3 (stromelysin) in rheumatoid synovioblasts (B cells): correlation with rheumatoid arthritis
}

\author{
YASUNORI OKADA, ${ }^{1}$ NAOTO TAKEUCHI, ${ }^{2}$ KATSURO TOMITA, ${ }^{2}$ \\ ISAO NAKANISHI, ${ }^{1}$ AND HIDEAKI NAGASE
}

From the Departments of ${ }^{1}$ Pathology and ${ }^{2}$ Orthopedic Surgery, School of Medicine, Kanazawa University, 13-1 Takara-machi, Kanazawa, Ishikawa 920, Japan; and the ${ }^{3}$ Department of Biochemistry, University of Kansas Medical Center, 39th and Rainbow Blvd, Kansas City, KS 66103, USA

SUMMARY Metalloproteinases produced by connective tissue cells may play a key part in the destruction of joints in rheumatoid arthritis. Matrix metalloproteinase 3 (MMP-3; stromelysin) capable of degrading cartilage proteoglycans and type IX collagen and of activating procollagenase was immunolocalised in hyperplastic synovial lining cells in rheumatoid synovium, but not in the cells of normal synovium. Cells responsible for synthesis of MMP-3 have the phenotype of synovioblasts (B cells) by immunoelectron microscopy, but not of phagocytic synovial macrophages (A cells). Cultured monolayer of rheumatoid synovial cells synthesises MMP-3 only under treatment with macrophage conditioned medium. Immunolocalisation of MMP-3 in rheumatoid synovium and cultured synovial cells was possible when the specimens were treated with a monovalent ionophore, monensin. These results suggest that MMP-3 is synthesised and secreted continuously without storage from hyperplastic synovioblasts stimulated by factor(s) derived from activated macrophages present in the synovium.

In rheumatoid arthritis the joints affected show chronic proliferative synovitis that causes destruction of articular cartilage, subchondral bones, tendons, and ligaments, resulting in deformity and disability of the joints. Although mechanical factors or oxygen derived free radicals, or both, may contribute to progressive damage in inflamed joints, the degradation of the major extracellular matrix components of articular cartilage, proteoglycans, and collagens can be attributed to proteolytic enzymes. ${ }^{1}$ All classes of proteinases have been implicated in the degradation of connective tissue matrix components in various forms of arthritis. ${ }^{2}$ Among them, matrix metalloproteinases (MMPs) derived from connective tissue cells are considered to play an important part in joint destruction during the long course of rheumatoid arthritis. They include collagenase (EC 3.4.24.7) that digests col-

Accepted for publication 6 January 1989.

Correspondence to Dr Yasunori Okada, Department of Pathology, School of Medicine, Kanazawa University, 13-1 Takara-machi, Kanazawa, Ishikawa 920, Japan. lagen types I, II, III, and X,,$^{3-5}$ MMP-2 (also called 'gelatinase'), ${ }^{6} 7$ and MMP-3 (stromelysin). ${ }^{89}$ Their synthesis and secretion are induced by factors such as interleukin $1,{ }^{10}$ tumour necrosis factor $\alpha,{ }^{11}$ and substance P. ${ }^{12}$ MMP-3 degrades a wide spectrum of extracellular matrix macromolecules, including cartilage proteoglycans, fibronectin, type IV collagen, and laminin. It also cleaves type IX collagen (manuscript in preparation), a recently characterised collagen that stabilises cartilage by interacting with the triple helical domains of the type II collagen molecule. ${ }^{1314}$ In addition, an endogenous activator of procollagenase reported in various connective tissues in culture ${ }^{15-17}$ has been proved to be MMP-3 (stromelysin). ${ }^{18}{ }^{19}$ Direct evidence of the involvement of MMP-3 in rheumatoid arthritis has not been obtained, however, and identification of the cells leading to the synthesis and secretion of MMP-3 has not been investigated. Here we report that MMP-3 is immunolocalised in hyperplastic synovial lining cells and its synthesis is specific to synovioblasts (B cells) of rheumatoid synovium. 


\section{Materials and methods}

PURIFICATION OF ACTIVE AND PRECURSOR FORMS OF MMP-3

Active MMP-3 with relative molecular weight (Mr) 28000 and 45000 and the precursor forms with $\mathrm{Mr}$ 57000 and 59000 (proMMP-3) were purified to homogeneity from the culture medium of rheumatoid synovial cells treated with macrophage conditioned medium as described.$^{820}$ Enzymic activities against $\left[{ }^{14} \mathrm{C}\right]$ collagen, $\left[{ }^{14} \mathrm{C}\right]$ gelatin, and $\left[{ }^{3} \mathrm{H}\right]$ carboxymethylated transferrin were assayed as described. ${ }^{8}$ Purified proMMP-3 (17 $\left.\mu \mathrm{g}\right)$ of Mr 57000 was coupled to cyanogen bromide activated Sepharose 4B (Pharmacia Fine Chemicals) according to the manufacturer's directions and used for the absorption of the specific antibody.

PREPARATION AND CHARACTERISATION OF ANTIBODY TO MMP-3

A $50 \mu \mathrm{g}$ sample of purified MMP-3 with Mr 28000 was emulsified with an equal volume of Freund's complete adjuvant (Difco Laboratories) and injected into an adult male sheep. Two further subcutaneous injections- $-30 \mu \mathrm{g}$ and $10 \mu \mathrm{g}$ of enzyme in incomplete adjuvant-were given after 14 and 24 days. A preimmune bleed and further bleeds were taken on days $0,14,24,35,46,49,56,60$, and 67 . The titre was checked by double immunodiffusion on Ouchterlony plates. Immunoglobulin $\mathbf{G}$ was prepared from the antiserum with the highest titre and preimmune serum by precipitation with ammonium sulphate ( $30 \%$ saturation) and column chromatography on diethylaminoethyl cellulose equilibrated with $0.1 \mathrm{M}$ trometamol (TRIS)-HCl $\mathrm{pH}$ $8 \cdot 0 / 0 \cdot 02 \% \mathrm{NaN}_{3}$. IgG $\mathrm{F}\left(\mathrm{ab}^{\prime}\right)_{2}$ was purified by application of the IgG digested with $2 \%(w / v)$ pepsin for 49 hours at $37^{\circ} \mathrm{C}$ to a column of Ultrogel AcA $44(1.5 \times 115 \mathrm{~cm})$ equilibrated with phosphate buffered saline (PBS) containing $0.02 \% \mathrm{NaN}_{3}$.

The ability of the antibody to inhibit MMP-3 was checked by using purified active MMP-3 of $\mathrm{Mr}$ $45000^{8}$ in $\left[{ }^{3} \mathrm{H}\right]$ carboxymethylated transferrin and $\left[{ }^{14} \mathrm{C}\right]$ gelatin assays. Purified IgG $\mathrm{F}\left(\mathrm{ab}^{\prime}\right)_{2}$ treated with $2 \mathrm{mM}$ di-isopropyl fluorophosphate was incubated with the enzyme solutions (110 ng) for one hour at $37^{\circ} \mathrm{C}$ and for an additional two hours at $22^{\circ} \mathrm{C}$ before the enzyme assays. Inhibitory activities of the IgG $\mathrm{F}\left(\mathrm{ab}^{\prime}\right)_{2}$ to partially purified collagenase and pure MMP-2 from the culture medium of rheumatoid synovial cells were also examined in $\left[{ }^{14} \mathrm{C}\right]$ collagen and $\left[{ }^{14} \mathrm{C}\right]$ gelatin assays respectively.

Antibody specificity was studied by double immunodiffusion, immunoprecipitation, and electrophoretic immunoblotting. Double immunodiffusion was performed by the methods of Ouchterlony and
Nilsson. ${ }^{21}$ Immunoprecipitation of MMP-3 with the antiserum was carried out with a culture medium of $\vec{\Rightarrow}$ : $\left[{ }^{3} \mathrm{H}\right]$ leucine labelled . rheumatoid synovial cells $\stackrel{{ }^{\circ}}{7}$ stimulated with rabbit macrophage conditioned medium $^{22}$ according to the method of Nagase et al. ${ }^{23} \overline{\bar{\omega}}$ $\left[{ }^{3} \mathrm{H}\right]$ Leucine labelled MMP-3 was immunoprecipi- $-\frac{\mathcal{T}}{\sigma}$ tated before and after treatment with $1.5 \mathrm{mM}$ 4-응 aminophenyl mercuric acetate for two hours at $37^{\circ} \mathrm{C}$. For electrophoretic immunoblotting analysis $\vec{\circ}$ concentrated culture medium and two purifiedforms of proMMP-3 with Mr 57000 and $59000^{20} \vec{\omega}$ were electrophoresed in sodium dodecyl sulphate/ $/ \frac{\rho}{\nu}$ polyacrylamide gel $(10 \%$ total acrylamide) under reduced conditions. Proteins separated in the gel $i_{\infty}^{+}$ were electrotransferred to nitrocellulose paper. The 0 paper was incubated for one hour at $22^{\circ} \mathrm{C}$ in the antiserum diluted 1:1000 in PBS/1\% bovine serum $\mathrm{Or}$ albumin $/ 0.05 \%$ Tween 20 , washed, and incubated in an alkaline phosphatase conjugated rabbit IgG to sheep IgG (Cappel). Immunoreactive MMP-3 was visualised with $165 \mu \mathrm{g} / \mathrm{ml}$ of 5-bromo-4-chloro-3-은 indolyl phosphate (Sigma Chemical Co) and $330^{\stackrel{\rho}{+}}$ $\mu \mathrm{g} / \mathrm{ml}$ of nitroblue tetrazolium (Sigma Chemical Co) $\overrightarrow{0}$ in $0.1 \mathrm{M}$ trometamol- $\mathrm{HCl} \mathrm{pH} 9.5$ containing $0.1 \mathrm{M}$ $\mathrm{NaCl}$ and $5 \mathrm{mM} \mathrm{MgCl}_{2}$.

SYNOVIAL TISSUE AND CELL CULTURE Synovial tissue obtained at arthroplasty from nineo patients with classical (five cases) and definite (four cases) rheumatoid arthritis was cut into pieces and $\underset{\overrightarrow{2}}{\stackrel{2}{ }}$ incubated in Dulbecco's modified Eagle's medium containing $10 \%$ fetal calf serum in the presence or $\frac{5}{\supset}$ absence of $1 \mu \mathrm{M}$ monensin (Sigma Chemical Co) for 10,30 minutes, 1,2 , and 3 hours. The tissue specimens freshly excised or incubated with or without monensin were embedded in Tissue-Tek: OCT compound (Miles Scientific) without fixation, and frozen sections $(4-6 \mu \mathrm{m})$ were prepared for immunofluorescent studies. Another set of samples was fixed in periodate-lysine-paraformaldehydeo fixative ${ }^{24}$ for 15 hours at $4^{\circ} \mathrm{C}$ and embedded in Epon $\triangle$ 812 for immunohistochemistry of $1 \mu \mathrm{m}$ sections by을. the avidin-biotin-peroxidase complex method and immunoelectron microscopy. As controls, three samples of synovium with normal histology were $N$ obtained from an ankle joint of an amputated leg of a patient with malignant giant cell tumour, from ao knee joint at meniscectomy, and from an elbow joint of a patient with osteochondritis dessicans. $\frac{\mathrm{Q}}{\mathbb{Q}}$ They were treated with or without monensin in? Dulbecco's modified Eagle's medium containing $10 \%$ fetal calf serum for three hours and embeddedo in Tissue-Tek OCT compound. For ordinary histological examination synovial tissue used in this study was also fixed in formaldehyde, and paraffin sections were stained with haematoxylin and eosin. 
Dissociated cells in the first generation of passage were prepared from the above mentioned rheumatoid synovial tissue according to the method of Dayer $e t a l^{25}$ and cultured on two-well Lab-Tek slides (Miles Laboratories) in Dulbecco's modified Eagle's medium with $10 \%$ fetal calf serum for five to seven days. The cells were stimulated with macrophage conditioned medium for three to five days to produce a large amount of MMP-3 and then treated with or without $1 \mu \mathrm{M}$ monensin for 10 minutes to three hours. The cells that were not stimulated with macrophage conditioned medium were also treated with or without monensin to serve as control. Attempts to cultivate normal synovial cells for immunolocalisation were given up as very small amounts of tissue were obtained from the samples of normal synovium.

\section{IMMUNOHISTOCHEMICAL METHODS}

Rheumatoid synovial cells grown on Lab-Tek slides were fixed with periodate-lysine-paraformaldehyde fixative for two hours at $4^{\circ} \mathrm{C}$ and rinsed with PBS. The cells were incubated for two hours at room temperature with either sheep anti-(MMP-3) IgG $\mathrm{F}\left(\mathrm{ab}^{\prime}\right)_{2}(65-130 \mu \mathrm{g} / \mathrm{ml})$ or non-immune sheep IgG $F\left(a b^{\prime}\right)_{2}(65-130 \mu \mathrm{g} / \mathrm{ml})$. They were then washed and treated with fluorescein isothiocyanate(FITC) conjugated rabbit IgG to sheep IgG (Cappel, diluted 1:20) for one hour at room temperature. The cells were observed with an Olympus Vanox AH2-FL microscope fitted with standard FITC filters. Photographs were taken on Kodak Ektachrome 400 films uprated to 1600 ASA. To confirm the specificity of the antibody for MMP-3, antibody IgG F $\left(\mathrm{ab}^{\prime}\right)_{2}(130$ $\mu \mathrm{g} / \mathrm{ml}$ ) was allowed to react with proMMP-3Sepharose for two hours at room temperature, and the supernatant was used as the primary antibody for immunohistochemistry.

Frozen sections from rheumatoid or control normal synovium were washed free of fixative with PBS and reacted with either sheep anti-(MMP-3) IgG $\mathrm{F}\left(\mathrm{ab}^{\prime}\right)_{2}(65-130 \mu \mathrm{g} / \mathrm{ml})$ or non-immune sheep IgG $\mathrm{F}\left(\mathrm{ab}^{\prime}\right)_{2}(65-130 \mu \mathrm{g} / \mathrm{ml})$, followed by incubation with FITC conjugated rabbit anti-(sheep IgG) antibody (dilution $\times 20)$. Some sections were also reacted with sheep anti-(MMP-3) IgG $\mathrm{F}\left(\mathrm{ab}^{\prime}\right)_{2}$ absorbed with proMMP-3-Sepharose. Photographs were taken as described above.

Sections $(1 \mu \mathrm{m})$ prepared from Epon embedded materials were first treated with a saturated solution of $\mathrm{KOH}$ in ethanol for five minutes to remove Epon and incubated with either sheep anti-(MMP-3) IgG $\mathrm{F}\left(\mathrm{ab}^{\prime}\right)_{2} \quad(16 \mu \mathrm{g} / \mathrm{ml})$ or non-immune sheep IgG $F\left(a b^{\prime}\right)_{2}(16 \mu \mathrm{g} / \mathrm{ml})$ for one hour after blocking endogenous peroxidase with $3 \% \mathrm{H}_{2} \mathrm{O}_{2}$. They were then washed with PBS containing $0.05 \%$ Tween 20 , incubated with biotinated rabbit IgG to sheep IgG (Vector Laboratories, diluted 1:200) for 30 minutes and with an avidin-biotin-peroxidase complex (Vector Laboratories) for $\mathbf{3 0}$ minutes at room temperature. Colour was developed with $0.03 \% 3,3^{\prime}$ diaminobenzidine tetrahydrochloride in $50 \mathrm{mM}$ trometamol- $\mathrm{HCl} \mathrm{pH} 7.6$ containing $0.006 \% \mathrm{H}_{2} \mathrm{O}_{2}$.

For immunoelectron microscopy ultrathin sections mounted on nickel grids were treated briefly (30 seconds to one minute) with $15 \% \mathrm{KOH}$ in ethanol and reacted with either sheep anti-(MMP-3) IgG $\mathrm{F}\left(\mathrm{ab}^{\prime}\right)_{2}(16 \mu \mathrm{g} / \mathrm{ml})$ or non-immune sheep IgG $\mathrm{F}\left(\mathrm{ab}^{\prime}\right)_{2}(16 \mu \mathrm{g} / \mathrm{ml})$. They were then incubated with biotinated rabbit IgG to sheep IgG and with an avidin-biotin-peroxidase solution as described above. Grids were reacted with $2 \%$ (w/v) osmium tetroxide for five minutes and stained with uranyl acetate and lead citrate. Specimens were examined in a Hitachi HU-500 electron microscope $(75 \mathrm{kV})$ at a magnification ranging from 3000 to 10000 .

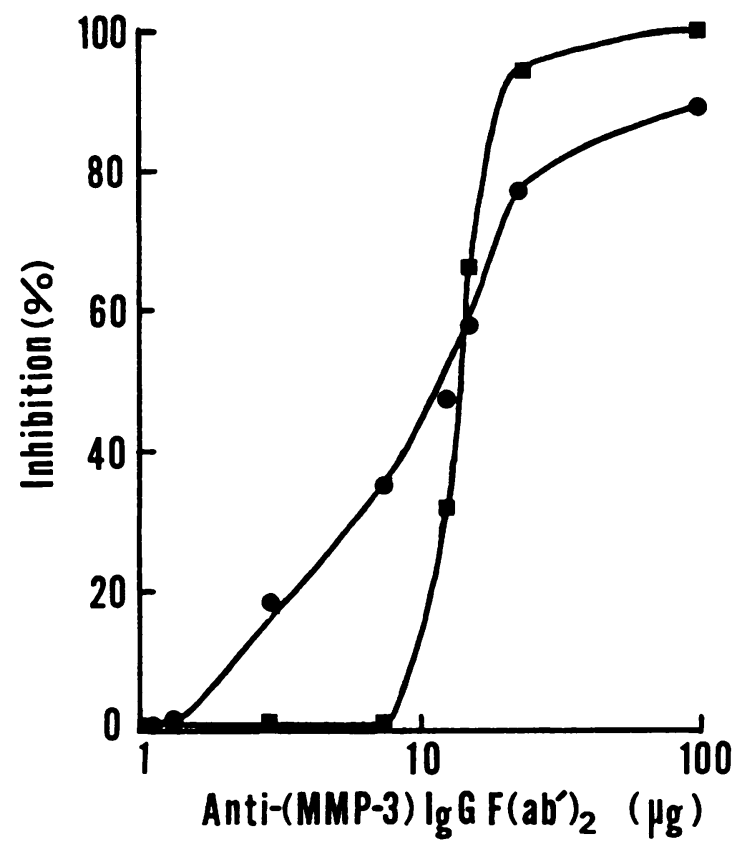

Fig. 1 Inhibition of matrix metalloproteinase 3 (MMP-3) activity by anti-(MMP-3) IgG F $\left(a b^{\prime}\right)_{2}$. Purified MMP-3 was incubated with different amounts of anti-(MMP-3) $\mathrm{IgG}$ $F\left(a b^{\prime}\right)_{2}$ as described in 'Materials and methods'. The residual activity of $M M P-3$ was assayed with $\left.{ }^{3} \mathrm{H}\right]$ carboxymethylated transferrin (O) and $\left[{ }^{14} \mathrm{C}\right.$ gelatin (-口) at $37^{\circ} \mathrm{C}$ for three and 16 hours respectively. Inhibitory activity was expressed as a percentage of the activity of the controls that were prepared by incubation without the antibody. Non-immune sheep $\operatorname{Ig} G F\left(a b^{\prime}\right)_{2}$ did not inhibit the enzyme activity (data not shown). 


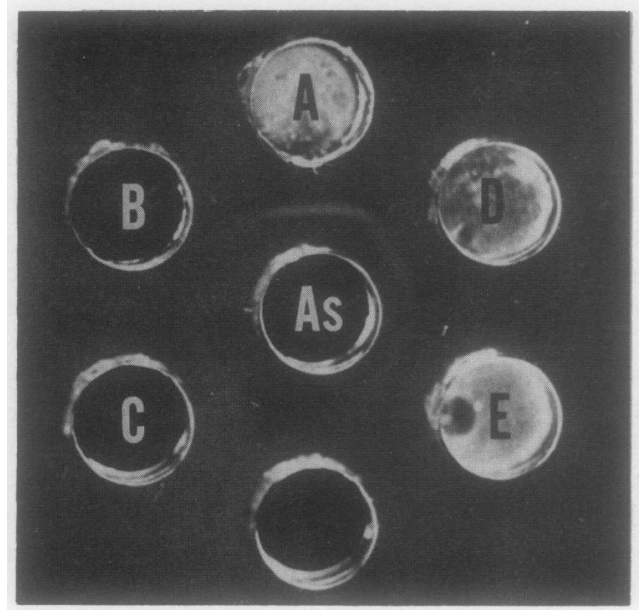

Fig. 2 Double immunodiffusion analysis of anti-matrix metalloproteinase 3 (anti-(MMP-3)) antiserum. As $=$ antiserum $(20 \mu \mathrm{l}) ; A=$ concentrated culture medium (2.0 units); $B=$ partially purified $M r 45000$ form of MMP-3 (1.2 units); C=purified MMP-3 of Mr 45000 ( 1.5 units); $D=$ partially purified $M r 28000$ form of MMP-3 (4.8 units); $E=$ purified MMP-3 of $M r 28000$ (6.0 units). One unit of MMP-3 activity is defined as that digesting $1 \mu \mathrm{g}$ of carboxymethylated transferrin in one minute at $37^{\circ} \mathrm{C}$.

\section{Results}

CHARACTERISATION OF THE ANTIBODY Purified IgG $\mathrm{F}\left(\mathrm{ab}^{\prime}\right)_{2}$ preparations of the antiserum against MMP-3 were tested for their ability to inhibit the enzymic activity of MMP-3 with Mr 45000 on two different substrates. The antibody inhibited the activity of MMP-3 by $89 \%$ in the $\left[{ }^{3} \mathrm{H}\right]$ carboxymethylated transferrin assay and by $100 \%$ in the $\left[{ }^{14} \mathrm{C}\right]$ gelatin assay (Fig. 1), but it did not inhibit the activities of collagenase or MMP-2 (data not shown).

In immunodiffusion a single line was observed when the antiserum was run against the crude culture medium and against the two partially purified and purified active forms of MMP-3 with $\mathrm{Mr}$ 28000 and 45000 (Fig. 2). The antiserum immunoprecipitated the zymogen of MMP-3 (Mr 57000 ) and its glycosylated form (Mr 59000$),{ }^{20}$ as well as an Mr 45000 form of MMP-3 from the crude culture medium partially activated with 4-aminophenylmercuric acetate (Fig. 3). Immunoblotting showed that IgG of the antiserum reacts with both active and zymogen forms of MMP-3 (Fig. 4). These data indicate that the antiserum is monospecific for MMP-3 and reacts with both active and zymogen forms of MMP-3.
IMMUNOLOCALISATION OF MMP-3 IN CULTURED RHEUMATOID SYNOVIAL CELLS The production of MMP-3 was first examined in cultured rheumatoid synovial cells. Dissociated cells $\bar{C}$ in the first generation of passage grown on Lab-Tek 듬. slides were stimulated with rabbit macrophage $\frac{\Phi}{\sqrt{T}}$

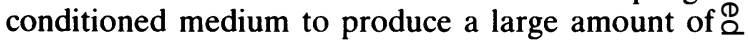
MMP-3. They were then incubated with or without $1 \stackrel{\infty}{\$}$ $\mu \mathrm{M}$ monensin, which is known to cause intracyto- $\vec{P}$ plasmic accumulation of metalloproteinases ${ }^{26}$ and tissue inhibitor of metalloproteinases. ${ }^{27}$ Figure $5 \mathrm{a} \vec{\omega}$ shows that about $95 \%$ of the cultured cells displayed $\stackrel{\sim}{\circ}$ bright fluorescence in the perinuclear region after $\frac{\varrho}{2}$ treatment with monensin for two to three hours. No fluorescence was detected when non-immune $\operatorname{IgG}_{\infty}^{\infty}$ $\mathrm{F}\left(\mathrm{ab}^{\prime}\right)_{2}$ was used as first antibody (Fig. 5b). Absorp- $\not$ tion of the antibody with purified zymogen of $\mathrm{cr}$

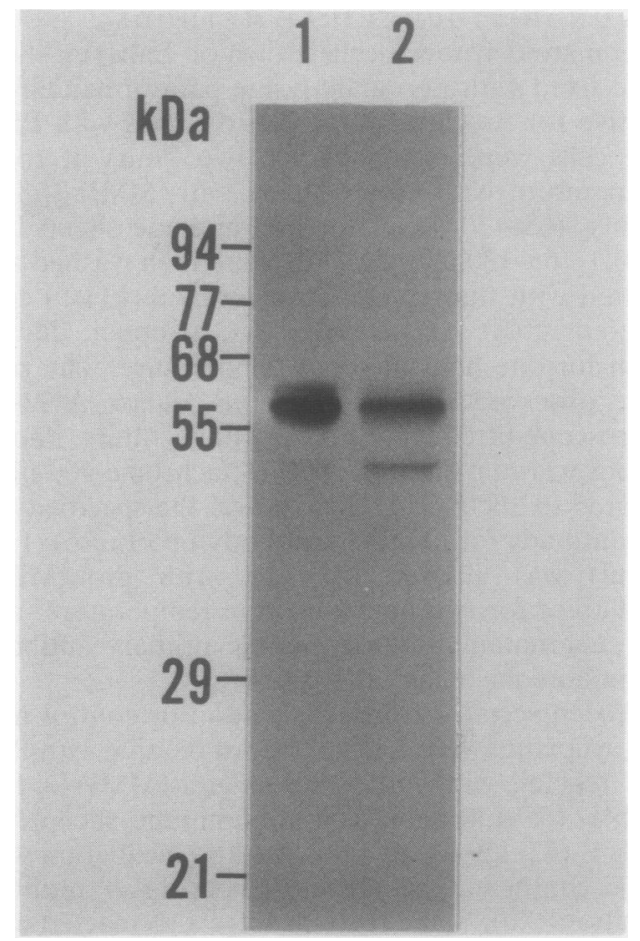

Fig. 3 Immunoprecipitation of $\left[{ }^{3} \mathrm{H}\right]$ leucine labelled matrix metalloproteinase 3 (MMP-3) with anti-(MMP-3) antiserum. Anti-(MMP-3) antiserum and protein $A$-Sepharose $C L-4 B$ were used to immunoprecipitate two precursor forms of ${ }^{3} \mathrm{H}$ ]leucine labelled MMP-3 $(\mathrm{Mr} 57000$ and 59 000) from culture medium (lane 1) and both ${ }^{3} \mathrm{H}$ precursors and an active form of $\left[^{3} \mathrm{H}\right] M M P-3(\mathrm{Mr} 45$ 000) from the culture medium treated with $1.5 \mathrm{mM}$ 4-aminophenylmercuric acetate for two hours at $37^{\circ} \mathrm{C}$ (lane 2). The samples were studied by $10 \%$ sodium dodecyl sulphatelpolyacrylamide gel electrophoresis and photofluorographed. 
MMP-3 abolished the labelling (Fig. 5c), indicating that the antibody and methods used are specific for the detection of MMP-3. Less intense fluorescence was seen within the cells treated with monensin for 30 minutes or one hour, and very little immunoreactive material was detected in less than $25 \%$ of the cells without monensin or with only a 10 minute treatment. Without stimulation with macrophage conditioned medium no fluorescence was observed, even when cells were treated with monensin for three hours.

IMMUNOFLUORESCENT LOCALISATION OF MMP-3 IN RHEUMATOID AND NORMAL S Y N O VIU M

Rheumatoid synovium fixed with formaldehyde and

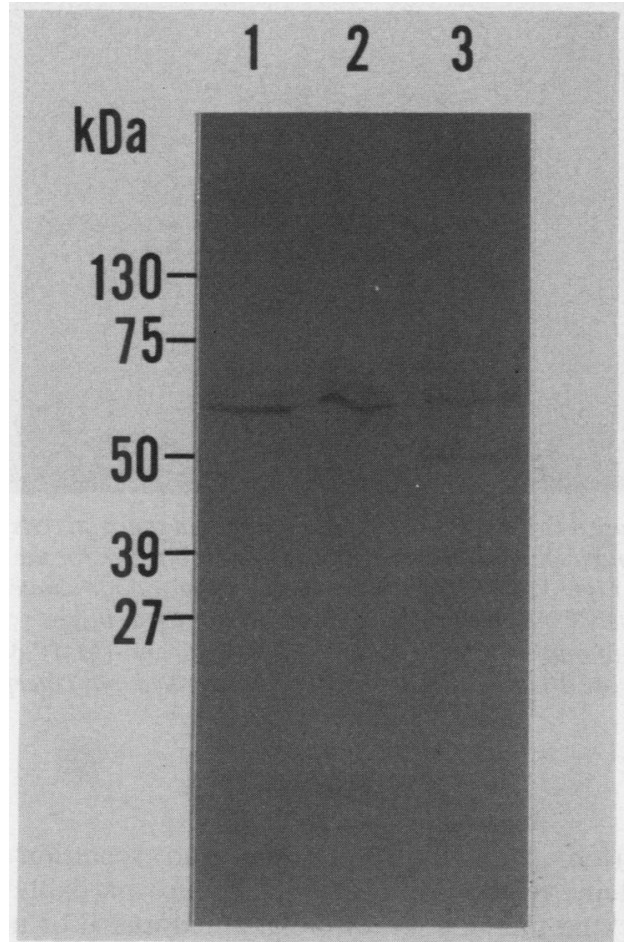

Fig. 4 Immunoblotting. Concentrated culture medium of rheumatoid synovial cells (lane 1), two purified zymogen forms of Mr 57000 and 59000 (lane 2), and the zymogen incubated with $1.5 \mathrm{mM}$ 4-aminophenylmercuric acetate for four hours at $37^{\circ} \mathrm{C}$ to produce active matrix metalloproteinase 3 (MMP-3) with Mr 45000 (lane 3) were electrophoresed on $10 \%$ sodium dodecyl sulphatel polyacrylamide gel under reducing conditions. The proteins in the gel were then electrotransferred to a nitrocellulose membrane and MMP-3 visualised using anti-(MMP-3) IgG and an alkaline phosphatase conjugated anti-(sheep IgG) antibody. The relative molecular weights $(\mathrm{Mr})$ of the prestained standards are indicated. stained with haematoxylin and eosin showed hyperplasia of synovial lining cells and lymph-mononuclear cell infiltration in the sublining cell layer (Fig. 6). Bright immunofluorescent precipitates were observed in most hyperplastic lining cells, especially in the perinuclear region, in all nine samples treated with monensin for three hours (Fig. 7). Very weak or no fluorescent staining was seen in the specimens freshly excised or those treated with monensin for a short period of time (10 minutes to one hour) or without monensin treatment. None of the specimens was fluorescence positive when reacted with nonimmune sheep IgG $\mathrm{F}\left(\mathrm{ab}^{\prime}\right)_{2}$ or with anti-(MMP-3) IgG $\mathrm{F}\left(\mathrm{ab}^{\prime}\right)_{2}$ absorbed with proMMP-3-Sepharose and when the first antibody was omitted. No immunoreactive materials were detected by the staining with anti-(MMP-3) $\operatorname{IgG~} \mathrm{F}\left(\mathrm{ab}^{\prime}\right)_{2}$ in three control synovia with normal histology even after a three hour treatment with monensin. IDENTIFICATION OF SYNOVIOBLASTS
(B CELLS) AS MMP-3 PRODUCING CELLS IN
RHEUMATOID SYNOVIUM

Sections $(1 \mu \mathrm{m})$ prepared from Epon embedded materials and stained by anti-(MMP-3) $\operatorname{IgG~F}\left(\mathrm{ab}^{\prime}\right)_{2}$ and the avidin-biotin-peroxidase method showed that hyperplastic synovial lining cells comprise two types of cells: major cells (approximately 60\%) intensively labelled with immunoperoxidase reaction products and cells without staining (Fig. 8). The former cells had oval cytoplasm with very few projections and showed perinuclear immunoreactive materials, whereas the latter were characterised by an indented nucleus and cytoplasmic processes. The immunoelectronmicroscopic properties of the cells reactive to anti-(MMP-3) antibody were characteristic of synovioblasts ${ }^{28}$ or B cells ${ }^{30}$ that have well developed rough endoplasmic reticulum and multiple Golgi apparatus. In monensin treated cells MMP-3 localised in Golgi related vacuoles that were caused by the action of monensin (Fig. 9). Synovial macrophages $^{2829}$ or A cells ${ }^{30}$ contained no immunoreactive materials. No immunoreactive materials were seen in the specimens reacted with non-immune sheep $\operatorname{IgG~} \mathrm{F}\left(\mathrm{ab}^{\prime}\right)_{2}$.

\section{Discussion}

Probably, in rheumatoid arthritis the proteinases have a major role in degradation of extracellular matrix macromolecules of articular cartilage and other joint components. Thus enzymes present in synovial fluid and released by the proliferative synovium and pannus have been examined by many investigators. They include cathepsin $\mathrm{D},{ }^{31}$ neutrophil elastase and cathepsin $G,{ }^{31-33}$ collagenase, ${ }^{34} 35$ 
Fig. 5 Immunohistochemical localisation of matrix metalloproteinase 3 (MMP-3) in cultured rheumatoid synovial cells Rheumatoid synovial cells were cultured as described in 'Materials and methods' and treated with $1 \mu M$ monensin for the final three hours. (a) The cells were stained with sheep anti-(MMP-3) $\operatorname{Ig} G F\left(a b^{\prime}\right)_{2}$ followed by fluorescein isothiocyanate (FITC) conjugated anti-(sheep IgG) antibody. Note that approximately $95 \%$ of the cells have adjoining nuclear bright fluorescence (arrows). ( $b$ and c) The cells were reacted with (b) non-immune sheep IgG $F\left(a b^{\prime}\right)_{2}$ or with (c) anti-(MMP-3) IgG $F\left(a b^{\prime}\right)_{2}$ absorbed by proMMP-3 (Mr 57 000) coupled to Sepharose $4 B$ and stained with FITC conjugated anti-(sheep IgG) antibody. No staining is visible. Bars $=50 \mu \mathrm{m}$.

gelatinase, ${ }^{36}$ and MMP-3. ${ }^{8}$ The development of antisera to these proteinases is a useful tool for a study of their localisation and production in vivo; collagenase $^{37}$ and neutrophil cathepsin $G$ and elastase $^{38}$ have already been immunolocalised in rheumatoid synovial tissue. In this paper we have prepared the monospecific antiserum against MMP3 and used the antibody to show the synthesis and secretion of the enzyme in both rheumatoid synovium and synovial cells in culture.

The monovalent ionophore, monensin, has been used to immunolocalise secretory proteins such as procollagen and fibronectin, ${ }^{39}$ tissue inhibitor of metalloproteinases, ${ }^{27}$ collagenase and stromelysin ${ }^{26}$ in cultured connective tissue cells. It is reported to interfere with the processing and secretion of proteins from various cells in culture probably by blocking the function of Golgi apparatus at or nearo the trans-face. ${ }^{4041}$ As MMP-3 was clearly detected $N$ by its accumulation in the perinuclear region of the cultured cells only when cells were treated with ${ }_{\sigma}^{\omega}$ monensin for more than $\mathbf{3 0}$ minutes this indicates that the proteinase passes through the Golgi appar- - ? atus and is not stored in the cell after synthesis. This $\infty$ is consistent with the biochemical observation of procollagenase, which was shown to be synthesised and secreted within 35 minutes without storage after $\overrightarrow{\mathbb{D}}$ the initiation of its synthesis by rabbit synovial cells $\frac{?}{\mathrm{O}}$ in culture. ${ }^{23}$

Our study also showed that MMP-3 is synthesised 
by synovial lining cells in rheumatoid synovial tissue but not by normal synovial cells. The absence of immunoreactive material without monensin treatment indicates that MMP-3 is rapidly secreted after synthesis from rheumatoid synovial lining cells without intracellular storage, as shown in the cell culture system. The cellularity of inflamed synovium in rheumatoid arthritis is heterogeneous. Although there is a debate about the distinction of synovial lining cells, originally named A and B cells by Barland et al, ${ }^{30}$ accumulated evidence has indicated that synovial lining cells consist of two structurally and functionally different cell types: phagocytic synovial macrophages (A cells) and synthetic synovioblasts (B cells). ${ }^{28} \quad 29$ 42-44 Immunohistochemistry of $1 \mu \mathrm{m}$ sections from Epon embedded materials (Fig. 8) has clearly shown two types of lining cell with or without immunoreactive materials. According to our ultrastructural criteria the cells which produce MMP-3 are synoviobllasts (B cells).

In our parallel experiments with cultured rheumatoid synovial cells MMP-3 was detected only when cells were treated with macrophage conditioned

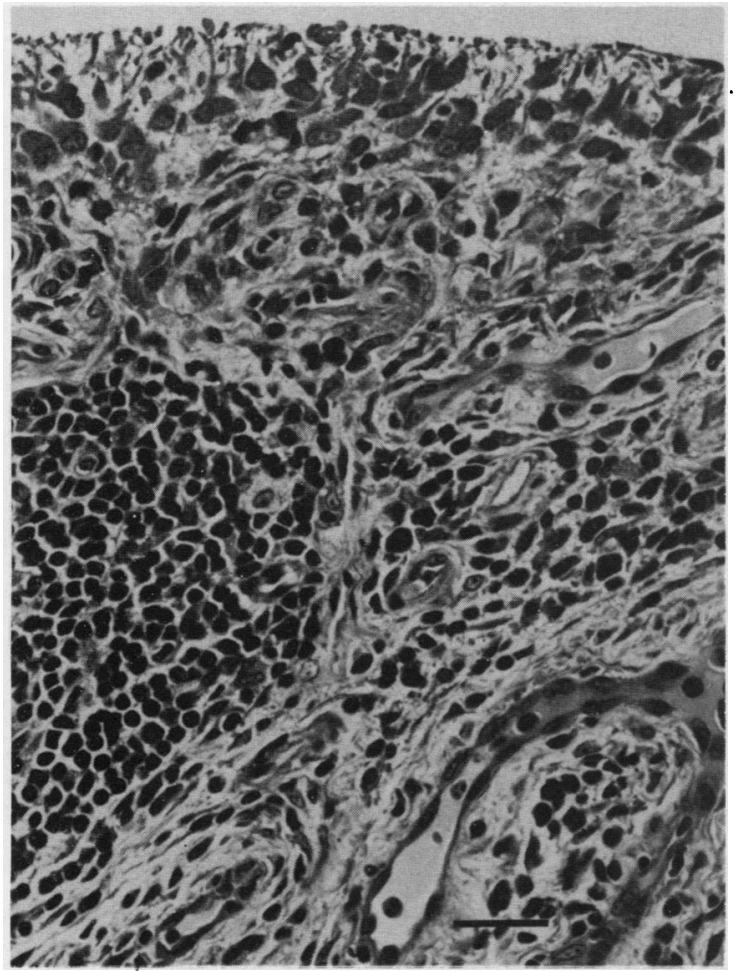

Fig. 6 Light photomicrograph of rheumatoid synovial tissue showing hyperplastic synovial lining cells and lymph-mononuclear cell infiltration in the sublining cell layer. Haematoxylin and eosin stain. Bar $=50 \mu \mathrm{m}$.

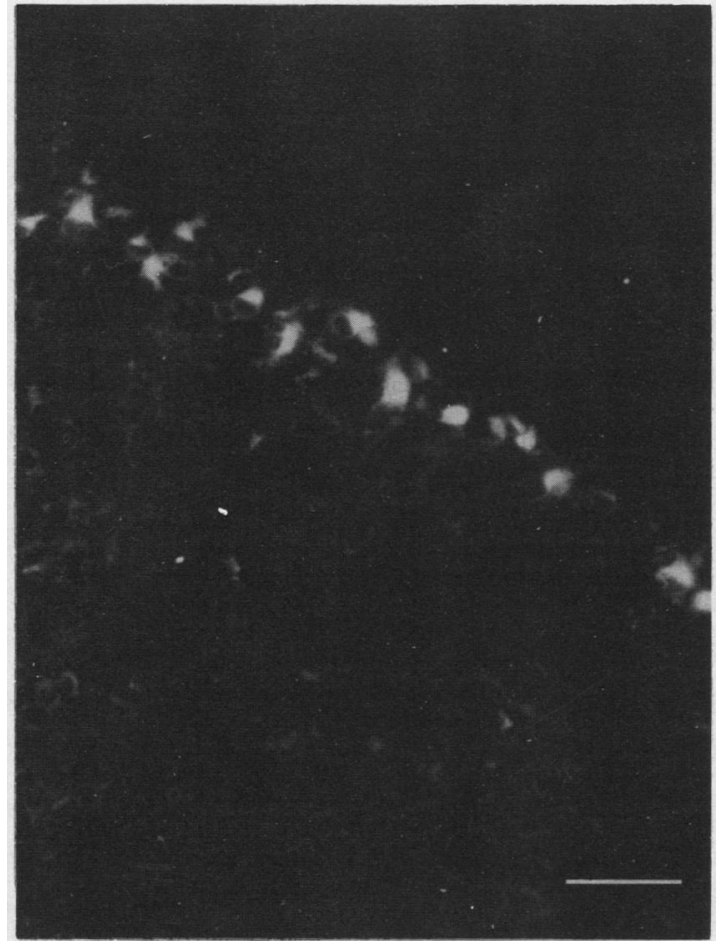

Fig. 7 Immunolocalisation of matrix metalloproteinase 3 (MMP-3) in rheumatoid synovial tissue. The tissue was treated with $1 \mu M$ monensin for three hours and frozen sections were stained by a fluorescein isothiocyanate immunofluorescent method with anti-(MMP-3) IgG $F\left(a b^{\prime}\right)_{2}$. Note bright immunofluorescence in hyperplastic lining cells. Bar $=50 \mu \mathrm{m}$.

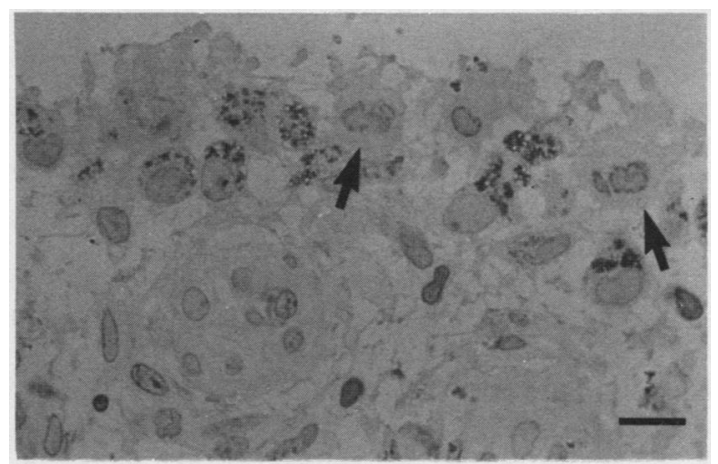

Fig. 8 Immunohistochemistry of matrix metalloproteinase $3(M M P-3)$ in Epon embedded rheumatoid synovial tissue. Rheumatoid synovial tissue incubated with $1 \mu M$ monensin for three hours was fixed with periodate-lysineparaformaldehyde fixative and embedded in Epon 812. Sections $(1 \mu \mathrm{m})$ were reacted with anti-(MMP-3) IgG $F\left(a b^{\prime}\right)_{2}$ followed by the avidin-biotin-peroxidase complex method and counterstained with toluidine blue. Two types of synovial lining cells showing positive and negative (arrows) immunoreactivity were observed. Bar $=10 \mu \mathrm{m}$. 
medium. This is in agreement with our previous biochemical studies. ${ }^{8}$ Factors relevant to the inflammation such as interleukin $1,{ }^{10} 26$ tumour necrosis factor $\alpha,{ }^{11}$ and substance $P^{12}$ stimulate cultured connective tissue cells to produce collagenase and MMP-3. Murphy et al immunolocalised collagenase and MMP-3 (stromelysin) in interleukin 1 stimulated rabbit articular chondrocytes in culture. ${ }^{26}$ Histological studies of human rheumatoid synovium, in contrast with control normal synovium, show marked infiltration of inflammatory cells containing macrophages and lymphocytes in the sublining cell layer and hyperplasia of the lining cells, suggesting that interleukin 1 and tumour necrosis factor $\alpha$ generated by activated macrophages might regulate the production of MMP-3 and collagenase in rheumatoid arthritis.

Matrix metalloproteinases are secreted from the cells as inactive zymogens. The key step appears to be the activation of proMMP-3, as MMP-3 can both degrade various extracellular matrix components ${ }^{8}$ and activate procollagenase. ${ }^{1819}$ Our recent biochemical studies showed that various proteinases, such as plasma kallikrein, ${ }^{20}$ plasmin, ${ }^{20}$ neutrophil elastase, and cathepsin G (unpublished work), can activate proMMP-3. Thus in inflamed joints it is likely that proteinases derived from plasma, tissue, or inflammatory cells can initiate the activation of
Fig. 9 Demonstration of matrix metalloproteinase 3 (MMP-3) in the rheumatoid synovioblast $(B$ cell) by immunoelectromicroscopy Ultrathin sections from Epon embedded synovial tissue treated with monensin were stained with sheep anti-(MMP-3) IgG $F\left(a b^{\prime}\right)$ followed by the avidinbiotin-peroxidase complex method. After reaction the section were stained with uranyl acetate $\infty$ and lead citrate. Note the presence 0 of the reaction products in Golgi cि related vacuoles (arrows) of a synovioblast ( $B$ cell) characterised by well developed rough endoplasmic reticulum and multiple Golgi apparatus. Bar $=1 \mu m$.

proMMP-3 and the subsequent activation of procollagenase.

We are grateful to Dr Edward D Harris Jr of the Department of Medicine, Stanford University, Stanford, CA, for his support and encouragement. This work was supported by Uehara Memorial Foundation and grant-in-aid (63570142) from the Ministry of Education, Science, and Culture of Japan to YO and by NIH gran AR 39189 to HN.

\section{Addendum}

Our recent data, quoted in this paper as unpublished work, have been accepted and published (FEBS Lett 1989; 244: 473-6 an $F E B S$ Lett (in press)).

\section{References}

1 Harris E D Jr. Pathogenesis of rheumatoid arthritis and the development of rational drug therapy. J Rheumatol 1982; 8: 3-9.

2 Barrett A J, Saklatvala J. Proteinases in joint disease. In: Kelley W N, Harris E D Jr, Ruddy S, Sledge C B, eds. C Textbook of rheumatology. Philadelphia: Saunders, 1981: 195-209.

3 Woolley D E, Glanville R W, Crossley M J, Evanson J M. Purification of rheumatoid synovial collagenase and its action on soluble and insoluble collagen. Eur J Biochem 1975; 54: 611-22.

4 Welgus H G, Jeffrey J J, Eisen A Z. The collagen substrate specificity of human skin fibroblast collagenase. $J$ Biol Chem 1981; 256: 9511-5.

5 Schmid T M, Mayne R, Jeffrey J J, Linsenmayer T F. Type X collagen contains two cleavage sites for a vertebrate collagenase. J Biol Chem 1986; 261: 4184-9. 
6 Seltzer J L, Adamis S A, Grant G A, Eisen A Z. Purification and properties of a gelatin-specific neutral protease from human skin. J Biol Chem 1981; 256: 4662-8.

7 Murphy G, McAlpine C G, Poll C T, Reynolds J J. Purification and characterization of a bone metalloproteinase that degrades gelatin and type IV and V collagen. Biochim Biophys Acta 1985; 831: 49-58.

8 Okada Y, Nagase H, Harris E D Jr. A metalloproteinase from human rheumatoid synovial fibroblasts that digests connective tissue matrix components. Purification and characterization. $J$ Biol Chem 1986; 261: 14245-55.

9 Chin J R, Murphy G, Werb Z. Stromelysin, a connective tissuedegrading metalloendopeptidase secreted by stimulated rabbit synovial fibroblasts in parallel with collagenase. $\mathrm{J}$ Biol Chem 1985; 260: 12367-76.

10 Mizel S B, Dayer J-M, Krane S M, Mergenhagen S E. Stimulation of rheumatoid synovial cell collagenase and prostaglandin production by partially purified lymphocyte-activating factor (interleukin 1). Proc Natl Acad Sci USA 1981; 78: 2474-7.

11 Dayer J-M, Beutler B, Cerami A. Cachectin/tumor necrosis factor stimulates collagenase and prostaglandin $E_{2}$ production by human synovial cells and dermal fibroblasts. J Exp Med 1985; 162: 2163-8.

12 Lotz M, Carson D A, Vaughan J H. Substance P activation of rheumatoid synoviocytes: neural pathway in pathogenesis of arthritis. Science 1987; 235: 893-5.

13 Müller-Glauser W, Humbel B, Glatt M, Sträuli P, Winterhalter $K \mathbf{H}$, Bruckner P. On the role of type IX collagen in the extracellular matrix of cartilage: type IX collagen is localized to intersections of collagen fibrils. J Cell Biol 1986; 102: 1931-9.

14 Eyre D R, Apon S, Wu J-J, Ericsson L H, Walsh K A. Collagen type IX: evidence for covalent linkage to type II collagen in cartilage. FEBS Lett 1987; 220: 337-41.

15 Vater C A, Nagase H, Harris E D Jr. Purification of an endogenous activator of procollagenase from rabbit synovial fibroblast culture medium. J Biol Chem 1983; 258: 9374-82.

16 Treadwell B V, Neidel J, Pavia M, Towle C A, Trice M E, Mankin H J. Purification and characterization of collagenase activator protein synthesized by articular cartilage. Arch Biochem Biophys 1986; 251: 715-23.

17 Ishibashi M, Ito A, Sakyo K, Mori Y. Procollagenase activator produced by rabbit uterine cervical fibroblasts. Biochem J 1987; 241: $527-34$.

18 Murphy G, Cockett M I, Stephens P E, Smith B J, Docherty A J P. Stromelysin is an activator of procollagenase. A study with natural and recombinant enzymes. Biochem $J$ 1987; 248: 265-8.

19 Ito A, Nagase H. Evidence that human rheumatoid synovial matrix metalloproteinase 3 is an endogenous activator of procollagenase. Arch Biochem Biophys 1988; 267: 211-6.

20 Okada Y, Harris E D Jr, Nagase H. The precursor of a metalloendopeptidase from human rheumatoid synovial fibroblasts. Purification and mechanisms of activation by endopeptidases and 4-aminophenylmercuric acetate. Biochem J 1988; 254: 731-41.

21 Ouchterlony O, Nilsson L A. Immunodiffusion and immunoelectrophoresis. In: Weir D M, ed. Handbook of experimental immunology. 2nd ed. Oxford: Blackwell Scientific, 1973: 19.1-39.

22 Mainardi C L, Seyer J M, Kang A H. Type-specific collagenolysis: a type $\mathrm{V}$ collagen-degrading enzyme from macrophages. Biochem Biophys Res Commun 1980; 9: 1108-15.

23 Nagase $H$, Brinckerhoff C E, Vater C A, Harris E D Jr Biosynthesis and secretion of procollagenase by rabbit synovial fibroblasts. Inhibition of procollagenase secretion by monensin and evidence for glycosylation of procollagenase. Biochem $J$ 1983; 214: 281-8.
24 McLean I W, Nakane P K. Periodate-lysine-paraformaldehyde fixative: a new fixative for immunoelectron microscopy. $J$ Histochem Cytochem 1974; 22: 1077-83.

25 Dayer J-M, Krane S M, Russell R G G, Robinson D R. Production of collagenase and prostaglandins by isolated adherent rheumatoid synovial cells. Proc Natl Acad Sci USA 1976; 73: 945-9.

26 Murphy G, Hembry R M, Reynolds J J. Characterisation of a specific antiserum to rabbit stromelysin and demonstration of the synthesis of collagenase and stromelysin by stimulated rabbit articular chondrocytes. Coll Relat Res 1986; 6: 351-64.

27 Hembry R M, Murphy G, Reynolds J J. Immunolocalization of tissue inhibitor of metalloproteinases (TIMP) in human cells. J Cell Sci 1985; 73: 105-19.

28 Okada Y, Nakanishi I, Kajikawa K. Ultrastructure of the mouse synovial membrane. Development and organization of the extracellular matrix. Arthritis Rheum 1981; 24: 835-43.

29 Okada Y, Nakanishi I, Munehiro C, Umeda S, Ichizen H, Masuda S. The presence of siderosomes in synovioblasts (B cells) of chronic spontaneous hemarthrosis. Histologic, electron microscopic, and roentgenographic electron microanalysis studies of three cases. Arch Pathol Lab Med 1984; 108: 968-72.

30 Barland P, Novikoff A B, Hamerman D. Electron microscopy of the human synovial membrane. J Cell Biol 1962; 14: 207-20.

31 Roughley P J. The degradation of cartilage proteoglycans by tissue proteinases. Proteoglycan heterogeneity and the pathway of proteolytic degradation. Biochem J 1979; 167: 639-46.

32 Keiser H, Greenwald R A, Feinstein G, Janoff A. Degradation of cartilage proteoglycan by human leukocyte neutral proteases-a model of joint injury. II. Degradation of isolated bovine nasal cartilage proteoglycan. J Clin Invest 1976; 57: 625-32.

33 Barrett A J. The possible role of neutrophil proteinases in damage to articular cartilage. Agents Actions 1973; 8: 11-18.

34 Evanson J M, Jeffrey J J, Krane S M. Studies on collagenase from rheumatoid synovium in tissue culture. J Clin Invest 1968: 47: $2639-51$.

35 Harris E D Jr, DiBona D R, Krane S M. Collagenases in human synovial fluid. J Clin Invest 1969; 48: 2104-13.

36 Harris E D Jr, Krane S M. An endopeptidase from rheumatoid synovial culture. Biochim Biophys Acta 1972; 258: 566-76.

37 Woolley D E, Crossley M J, Evanson J M. Collagenase at sites of cartilage erosion in the rheumatoid joint. Arthritis Rheum 1977; 20: 1231-9.

38 Velvart M, Fehr K. Degradation in vivo of articular cartilage in rheumatoid arthritis and juvenile chronic arthritis by cathepsin $\mathrm{G}$ and elastase from polymorphonuclear leukocytes. Rheumatol Int 1987; 7: 195-202.

39 Ledger $\mathrm{P}$ W, Uchida N, Tanzer M L. Immunocytochemical localization of procollagen and fibronectin in human fibroblasts: effects of the monovalent ionophore, monensin. J Cell Biol 1980; 87: 663-71.

40 Tartakoff A M. Perturbation of vesicular traffic with the carboxylic ionophore monensin. Cell 1983; 32: 1026-8.

41 Morré D J. Morré D M, Mollenhauer H H, Reutter W. Golgi apparatus cisternae of monensin-treated cells accumulate in the cytoplasm of liver slices. Eur J Cell Biol 1987; 43: 235-42.

42 Linck G, Porte A. Cytophysiology of the synovial membrane: distinction of two cell types of the intima revealed by their reaction with horseradish peroxidase and iron saccharate in the mouse. Biol Cell 1981; 42: 147-52.

43 Graabaek P M. Ultrastructural evidence for two distinct types of synoviocytes in rat synovial membrane. $J$ Ultrastruct Res 1982; 78: 321-39.

44 Edwards J C W, Willoughby D A. Demonstration of bone marrow derived cells in synovial lining by means of giant intracellular granules as genetic markers. Ann Rheum Dis 1982; 41: $177-82$. 